Quim. Nova, Vol. 36, No. 8, 1096-1100, 2013

\title{
CHEMICAL COMPOSITION OF VOLATILES FROM MALE AND FEMALE SPECIMENS OF Baccharis trimera COLLECTED IN TWO DISTANT REGIONS OF SOUTHERN BRAZIL: A COMPARATIVE STUDY USING CHEMOMETRICS
}

\author{
Michele Aparecida Besten and Domingos Sávio Nunes* \\ Departamento de Química, Universidade Estadual de Ponta Grossa, Av. Carlos Cavalcanti 4748, 84030-900 Ponta Grossa - PR, Brasil \\ Alberto Wisniewski Jr. \\ Departamento de Química, Universidade Federal de Sergipe, Rod. Mal. Rondon S/N, 49100-000 São Cristóvão - SE, Brasil \\ Sávio Luis Sens \\ Centro de Educação Tecnológica Irmão Mário Cristóvão (TECPUC), Rua Imaculada Conceição 1155, 80215-901 Curitiba - PR, \\ Brasil \\ Daniel Granato \\ Núcleo de Análise e Tratamento de Dados, Instituto Adolfo Lutz, Av. Dr. Arnaldo 355, 01246-902 São Paulo - SP, Brasil \\ Edésio Luis Simionatto, Dilamara Riva Scharf and Juliana Bastos Dalmarco \\ Laboratório de Cromatografia, Fundação Universidade Regional de Blumenau, Rua São Paulo 3250, 89030-000 Blumenau - SC, \\ Brasil \\ Nelson Ivo Matzenbacher \\ Departamento de Botânica, Universidade Federal do Rio Grande do Sul, Av. Bento Gonçalves 9500, B1. 4, Prédio 43433, \\ 91540-000 Porto Alegre - RS, Brasil
}

Recebido em 25/10/12; aceito em 5/5/13; publicado na web em 17/7/13

\begin{abstract}
GC/MS/FID analyses of volatile compounds from cladodes and inflorescences from male and female specimens of Baccharis trimera (Less.) DC. collected in the states of Paraná and Santa Catarina, Brazil, showed that carquejyl acetate was the primary volatile component (38\% to $73 \%$ ), while carquejol and ledol were identified in lower concentrations. Data were subjected to hierarchical cluster analysis and principal component analysis, which confirmed that the chemical compositions of all samples were similar. The results presented here highlight the occurrence of the same chemotype of B. trimera in three southern states of Brazil.
\end{abstract}

Keywords: Baccharis trimera; carqueja; carquejyl acetate.

\section{INTRODUCTION}

The section Caulopterae from the genus Baccharis is composed of plants that can look very similar to each other, making it difficult to differentiate them ${ }^{1}$ both in the field and based on their herbarium material. These plants are known as carquejas and they present with ribbed or winged stems (cladodes), ${ }^{2}$ and therefore can be recognized as a section by this distinguishing characteristic. ${ }^{3}$

Baccharis trimera (Less.) DC., Caulopterae (popularly known as carqueja), despite being widely studied, ${ }^{4,5}$ is hardly distinguishable from some other species in the same section; ${ }^{6}$ this represents a hurdle in maintaining the quality control of pharmaceutical products made from this plant. This is the only species of the genus that is contained in the first and fourth editions of the Brazilian Pharmacopoeia, ${ }^{7}$ representing its importance. ${ }^{8}$ Carqueja is traditionally used by the Brazilian population due to its analgesic and diuretic properties, to facilitate digestion, to diminish stomach aches, and to control hypertension and diabetes. ${ }^{9}$

A recent study reported interesting field observations and detailed morphological differences among several Caulopterae species that occur in the state of Rio Grande do Sul, Brazil..$^{10}$ As for taxonomic identification, B. trimera (Less.) DC. has been considered a synonym for Baccharis crispa Spreng., in spite of the differences that can be observed in plant populations occurring in natura, especially phenological differences. For example, flowers and fruits from $B$. trimera bloom from January to March, and their maximum production

*e-mail: dsnunes@pq.cnpq.br occurs in February, while B. crispa flowers and fruits do so between February and April, and their maximum production occurs in March. Another important factor to note is that bovine animals do not consume $B$. trimera even when available in large natural formations and when their pasture area is limited, while other species of the section Caulopterae, like B. crispa, Baccharis articulata (Lam.) Pers. and Baccharis stenocephala Baker, are avidly consumed.

To compare the compositions of essential oils from several species of the Caulopterae section collected in Rio Grande do Sul, Brazil and Argentina, B. articulata, B. crispa, Baccharis milleflora (Less.) DC., Baccharis myriocephala DC., B. stenocephala Baker, Baccharis junciformis DC. (also known as Baccharis usterii Hering) and B. trimera were investigated and carquejyl acetate was identified only in the essential oil from $B$. trimera.${ }^{11} \mathrm{~A}$ high proportion of this compound has also been found in the essential oil from $B$. trimera collected in the same Brazilian region during a study of volatile compounds obtained by supercritical $\mathrm{CO}_{2}$ extraction. ${ }^{12}$ Carquejyl acetate was occasionally found in samples collected in areas of Cerrado (Mogi Guaçu) and in the Atlantic Forest (Santo André), both of which are in the state of São Paulo. ${ }^{13}$ However, carquejol and carquejyl acetate (Figure 1) were not found when several other samples from the southeastern region of Brazil were analyzed..$^{5,14}$

Based on these considerations, this paper presents the first comprehensive analytical results about volatile compound compositions obtained from cladodes, flowers and shoots from male and female specimens of B. trimera collected in Southern Brazil. This research also aimed to evaluate the occurrence of variations in the compositions of volatile secondary metabolites by collecting the species in 
<smiles>C=C(C)[C@H]1C(=C)CC=C[C@@H]1OC(C)=O</smiles>

Carquejyl acetate<smiles>C=C(C)[C@H]1C(=C)CC=C[C@H]1O</smiles>

Carquejol
Figure 1. Chemical structures of carquejyl acetate, the main volatile component of Baccharis trimera, and its related alcohol carquejol

two distant locations and analyzing the chemical similarities among samples by utilizing a chemometric approach.

\section{EXPERIMENTAL}

\section{Collection, identification and preparation of plant material}

Male and female specimens of Baccharis trimera (Less.) DC. were collected in Segundo Planalto of Paraná in the state of Paraná, Brazil on February $1^{\text {st }}$ of 2011 at the borders of road PR-513 in the geographical position $25^{\circ} 08^{\prime} 20^{\prime \prime}$ South by $49^{\circ} 59^{\prime} 56^{\prime \prime}$ West at an altitude of 1,061 meters; specimens were also collected on January $18^{\text {th }}$ of 2011 in Alto Vale do Rio Itajaí, Rio do Sul, Santa Catarina, Brazil in the geographical position $27^{\circ} 16^{\prime} 00^{\prime \prime}$ South by $49^{\circ} 36^{\prime} 00^{\prime}$ ' West at an altitude of 530 meters. The botanical exsiccates were deposited at the Federal University of Rio Grande do Sul (UFRGS) Herbarium as ICN 174976 and ICN 174977. The male and female specimens from each region were collected at the same place, date and time. The samples used to assess the chemical composition were dried at room temperature for two days and the impurities were carefully separated to yield up to $100 \mathrm{~g}$ of inflorescences and cladodes of each plant species. The plant materials were stored in airtight jars in a freezer at $-18{ }^{\circ} \mathrm{C}$ until the extraction procedure. Table 1 summarizes the data of all materials tested.

Table 1. Information for all collections of B. trimera botanical materials

\begin{tabular}{ccccc}
\hline COLLECTION DAY & I & C & S & Codes* $^{*}$ \\
\hline $18 / 01 / 2011$ & & $\mathrm{x}$ & & BMCSC \\
$18 / 01 / 2011$ & & $\mathrm{x}$ & & BFCSC \\
$18 / 01 / 2011$ & $\mathrm{x}$ & & BMISC \\
$18 / 01 / 2011$ & $\mathrm{x}$ & & $\mathrm{BFISC}$ \\
$03 / 01 / 2011$ & & & SHOOTS \\
$01 / 02 / 2011$ & & $\mathrm{x}$ & & BMCPR \\
$01 / 02 / 2011$ & & $\mathrm{x}$ & & BFCPR \\
$01 / 02 / 2011$ & $\mathrm{x}$ & & BMIPR \\
$01 / 02 / 2011$ & $\mathrm{x}$ & & BFIPR \\
\hline
\end{tabular}

$* \mathrm{BM}=B$. trimera male $; \mathrm{BF}=B$. trimera female $; \mathrm{C}=$ cladodes $; \mathrm{I}=$ inflores cences; $\mathrm{S}=$ shoots; $\mathrm{SC}=$ Santa Catarina; $\mathrm{PR}=$ Paraná.

\section{Isolation and analysis of volatiles}

Approximately $100 \mathrm{~g}$ of male and female inflorescences or cladodes were ground separately and hydrodistilled for $3 \mathrm{~h}$ in a $2 \mathrm{~L}$ flask containing $1 \mathrm{~L}$ of distilled water. The flask was attached to a glass apparatus built according to a recommended design. ${ }^{15}$ The hydrodistilled volatiles were collected in ethyl ether, the remaining water was decanted and the solvent was evaporated at room temperature. The yields of the oils were calculated taking into consideration the initial plant material mass.

The volatiles were analyzed using a Varian ${ }^{\circledR}$ CP-3800 gas chromatograph with Saturn ${ }^{\circledR}$ GC/MS Workstation 5.51 software; the gas chromatograph was operated in EI mode at $70 \mathrm{eV}$ with a mass scan range of $40-650 \mathrm{~m} / \mathrm{z}$ at a sample rate of $1.0 \mathrm{scan} \mathrm{s}^{-1}$; a $30 \mathrm{~m}$ long CP-Sil-8 CB LowBleed/MS capillary column with a $0.25 \mathrm{~mm}$ diameter and a $0.25 \mu \mathrm{m}$ film was used. The temperature of the injector was maintained at $250{ }^{\circ} \mathrm{C}$ and the temperature of the interface was held at $240{ }^{\circ} \mathrm{C}$. A flow rate of $5 \mathrm{~mL} \mathrm{~min}{ }^{-1}$ was utilized and helium was the carrier gas. The injection volume was $1.0 \mu \mathrm{L}$ of oil (diluted in ethyl ether). The temperature was programmed to increase in accordance with the following conditions: $50{ }^{\circ} \mathrm{C}$ for the first minute, increase by $3{ }^{\circ} \mathrm{C} \mathrm{min}-1$ up to $240{ }^{\circ} \mathrm{C}$, and the split ratio was set to $1 / 50$. The relative retention indices were calculated using data from a series of n-alkanes (C10-C30) under the same conditions used for the volatile compounds. To validate the system and ensure the reliability of the calculated retention indexes, standards of $\alpha$-pinene, $\beta$-pinene, limonene, linalool, caryophyllene, spathulenol and viridiflorol were used. The relative composition of each oil sample was measured on a Shimadzu 14B gas chromatograph with a flame ionization detector (GC/FID) and a OV-5 column ( $30 \mathrm{~m}$ x $0.25 \mathrm{~mm}$ x $0.25 \mu \mathrm{m})$. Nitrogen was used as the carrier gas with a constant pressure of $80 \mathrm{kPa}$, a split ratio of 1/150 was used and the oil injection volume (diluted in ethyl ether) was $1 \mu \mathrm{L}$. The temperatures of the detector and the injector were kept at 300 and $250{ }^{\circ} \mathrm{C}$, respectively. The initial temperature in the column was $50{ }^{\circ} \mathrm{C}$ (for $3 \mathrm{~min}$ ), with a heating rate of $5{ }^{\circ} \mathrm{C} \mathrm{min}{ }^{-1}$ until the temperature reached $270{ }^{\circ} \mathrm{C}$, then the temperature was held constant for 8 min. ${ }^{16}$

\section{Application of chemometrics}

To assess associations between all the chemical compounds and highlight both chemical similarities and differences among $B$. trimera samples, pattern recognition methods were applied to the experimental data, namely principal component analysis (PCA) and hierarchical cluster analysis (HCA), which are unsupervised statistical methods.

PCA was applied to auto scaled data to describe the relationship between the samples; this method also checks to see if the data are similar or dissimilar and if the data represents typical data or outliers. The loading vectors describe the importance of each variable. PCA was applied to separate the samples $(n=9)$ according to their chemical markers $(n=27)$, totaling 243 data points. To organize the data for PCA, the chemical compound results were put into columns and the B. trimera samples were put into rows. Analyses were based on correlations and variances were calculated as SS/(n-1). Eigenvalues higher than 1.0 were adopted to explain the projection of the plant samples on the factor-plane (PC 1 vs PC 2), following the Kaiser criterium. ${ }^{17}$

HCA displays the data in a way that emphasizes natural clusters and patterns in a two-dimensional space. HCA was applied to auto scaled data using a one-step approach; the Ward's method was used as an amalgam rule and the Euclidean distances and metrics were used to generate a dendrogram of all samples. ${ }^{18}$ Comparison between the two suggested clusters was performed by the Student's t-test for independent samples after checking the homogeneity of variances using the F-test.

\section{RESULTS AND DISCUSSION}

The chemical constituents of the volatile compounds from all botanical materials analyzed in this study are shown in Table 2 . The monoterpenes class was the main chemical class in all samples, and this was due to the amount of carquejyl acetate present in the samples. The analyses presented here are the first reported in the literature that compare volatile compounds from male and female specimens of $B$. trimera collected in Southern Brazil. The chemical profile found in 
the present study was similar to that of essential oils from botanical materials from the state of Rio Grande do Sul, in which carquejyl acetate is represented in high proportions (40.7 to 73.5\%) and two other characteristic components represented lower proportions in all samples: ledol (6.0 to $17.5 \%)$ and carquejol (0.2 to $8.5 \%){ }^{11}$

Table 2. Yields and relative compositions (\%) of the volatiles from the cladodes and inflorescences of male and female specimens of Baccharis trimera collected in Paraná and Santa Catarina

\begin{tabular}{|c|c|c|c|c|c|c|c|c|c|}
\hline COMPONENT & $1 *$ & $2 *$ & $3 *$ & $4 *$ & $5^{*}$ & $6^{*}$ & $7 *$ & $8^{*}$ & $9 *$ \\
\hline$\beta$-pinene & 1.0 & 2.8 & 1.1 & 0.2 & 0.5 & 0.2 & 0.5 & 2.1 & 2,8 \\
\hline limonene & 0.2 & nd & nd & nd & nd & 0.1 & nd & nd & nd \\
\hline trans- $\beta$-ocimene & 0.4 & nd & 0.2 & 0.3 & 0.2 & 0.4 & 0.4 & nd & 0,4 \\
\hline linalool & 0.5 & nd & nd & 0.3 & 0.5 & 0.7 & nd & nd & 0,5 \\
\hline carquejol & 16.9 & 0.7 & 0.6 & 1.2 & 0.2 & 8.5 & 7.3 & 6.3 & 6,2 \\
\hline$\alpha$-terpineol & 0.1 & nd & nd & nd & nd & 0.1 & nd & nd & nd \\
\hline carquejyl acetate & 42.7 & 73.5 & 73.3 & 45.6 & 51.1 & 38.1 & 40.7 & 66.7 & 65,1 \\
\hline eugenol & 0.1 & nd & nd & nd & nd & 0.2 & nd & 0.3 & nd \\
\hline copaene & 0.1 & nd & nd & nd & nd & 0.1 & nd & nd & 0,3 \\
\hline$\alpha$-gurjunene & 0.3 & nd & 0.3 & 0.5 & 0.7 & 0.6 & 0.5 & nd & nd \\
\hline caryophyllene & 1.0 & nd & 0.4 & 1.3 & 3.5 & 1.5 & 2.1 & 0.3 & nd \\
\hline$\alpha$-caryophyllene & 0.1 & nd & 0.3 & 1.1 & 0.7 & 0.9 & nd & 0.4 & nd \\
\hline$\gamma$-gurjunene & 0.1 & nd & nd & nd & nd & nd & nd & nd & nd \\
\hline$\gamma$-muulorene & 0.1 & nd & nd & 0.6 & 0.5 & 0.7 & nd & 0.3 & nd \\
\hline germacrene-D & 4.2 & 3.9 & 4.9 & 6.9 & 9.7 & 6.2 & 4.4 & 3.1 & 3.1 \\
\hline elixene & 2.4 & 1.8 & 1.5 & 4.2 & 4.0 & 4.4 & 6.2 & 1.7 & 2.0 \\
\hline$\alpha$-bulnesene & 1.8 & 0.7 & 0.7 & 1.5 & 1.5 & 1.0 & 0.5 & 0.5 & 0.3 \\
\hline$\gamma$-cadinene & 0.1 & nd & nd & 0.5 & nd & 0.5 & 0.4 & nd & nd \\
\hline$\delta$-cadinene & 0.9 & 0.9 & 0.8 & 2.0 & 1.6 & 1.2 & 1.0 & 0.6 & 0.6 \\
\hline elemol & 0.1 & 0.8 & 0.7 & 0.5 & 0.4 & 0.3 & nd & 0.4 & 0.3 \\
\hline ledol & 12.6 & 6.0 & 7.7 & 17.0 & 15.1 & 14.9 & 17.5 & 7.0 & 7.7 \\
\hline spathulenol & 0.2 & nd & 0.4 & 0.3 & nd & 0.2 & 0.6 & nd & 0.2 \\
\hline caryophyllene oxide & 0.3 & nd & nd & 0.5 & 0.4 & 0.3 & 0.7 & nd & nd \\
\hline viridiflorol & 0.6 & 0.6 & 0.3 & 1.2 & 0.7 & 3.6 & 3.5 & 1.6 & 1.0 \\
\hline$\gamma$-eudesmol & 0.2 & nd & nd & 0.2 & 0.2 & 0.1 & nd & nd & nd \\
\hline eudesmol & 2.7 & 5.0 & 2.9 & 4.5 & 1.5 & 4.4 & 5.5 & 4.0 & 5.1 \\
\hline Total (\%) & 90.0 & 96.7 & 96.2 & 90.7 & 93.0 & 89.5 & 92.0 & 95.5 & 95.4 \\
\hline Yield $(\%, w / w)$ & 0.52 & 1.83 & 2.14 & 0.50 & 0.63 & 0.30 & 0.37 & 1.43 & 1.44 \\
\hline
\end{tabular}

$1^{*}=$ SHOOTS $; 2^{*}=\mathrm{BFCPR} ; 3^{*}=\mathrm{BMCPR} ; 4^{*}=\mathrm{BFIPR} ; 5^{*}=\mathrm{BMIPR} ; 6^{*}=$ BFISC; $7^{*}=$ BMISC; $8^{*}=$ BFCSC; $9^{*}=$ BMCSC; nd $=$ not detected by GC/ MS or the content was below $0.10 \%$ when GC/FID was used.

The yields for each volatile oil are shown in the last line of Table 2 , where it is observed that the highest yield was obtained for oils extracted from samples collected in Paraná. The yields of volatile compounds from cladodes of B. trimera were about $1 \%$ to $2 \%$, confirming the high yields found in the literature. ${ }^{11}$ An opposite behavior was observed for inflorescences $(0.3 \%-0.5 \%$ yield). Another important observation was that oils obtained from male specimens virtually always presented higher yields as compared to female specimens.

The analyses also indicated that carquejyl acetate was found in higher proportions in cladodes, whereas ledol and carquejol are more prominent in the inflorescences. The volatile oils from buds presented a higher concentration of carquejol (17.0\%) as compared to all other samples.

PCA (Figure 2) showed that the first three components explained up to $83 \%$ of the variability in the data, and the projections of the $B$. trimera samples were clearly separated into two distinct groups: Group 1 comprised BFCPR, BMCSC, BMCSC, and BMCPR, whereas Group 2 comprised BMIPR, SHOOTS, BFISC, BMISC, and
BFIPR. This initial separation was further confirmed using HCA for the samples (Figure 3 ). Figure 2B shows the factor analysis using the response variables tested in this study, that is, which variables were responsible for the projection of samples in the factor plane (PC $1 \mathrm{x}$ PC 2). In summary (Table 3), by examining the scatterplot (PC $1 \mathrm{x}$ PC 2) obtained by PCA and the dendrogram for samples obtained by HCA, it is observed that the first group consists of samples of volatiles extracted from cladodes, whereas the volatile compounds contained in Group 2 were obtained from shoots or inflorescences (shoots). By using these chemometric tools, it was possible to compare the degree of similarity among samples and variables simultaneously, which is a great advantage compared to univariate methods, such as analysis of variances (ANOVA).

Table 3. Correlation between the original variables and the first three principal components

\begin{tabular}{lccc}
\hline COMPONENT & PC1 & PC2 & PC3 \\
\hline$\beta$-pinene & $\mathbf{- 0 . 9 2}$ & -0.14 & -0.05 \\
trans- $\beta$-ocimene & $\mathbf{0 . 6 6}$ & -0.41 & -0.45 \\
linalool & $\mathbf{0 . 5 0}$ & 0.19 & $\mathbf{- 0 . 6 2}$ \\
carquejol & 0.16 & $\mathbf{- 0 . 5 1}$ & $\mathbf{- 0 . 8 0}$ \\
carquejyl acetate & $\mathbf{- 0 . 9 3}$ & 0.21 & 0.27 \\
$\alpha$-gurjunene & $\mathbf{0 . 9 2}$ & 0.25 & 0.02 \\
caryophyllene & $\mathbf{0 . 8 0}$ & 0.25 & 0.01 \\
$\alpha$ - caryophyllene & $\mathbf{0 . 6 0}$ & 0.59 & 0.16 \\
$\gamma$-muulorene & $\mathbf{0 . 6 6}$ & 0.50 & 0.02 \\
germacrene D & $\mathbf{0 . 6 7}$ & 0.67 & 0.11 \\
elixene & $\mathbf{0 . 8 9}$ & -0.30 & 0.27 \\
$\alpha$-bulnesene & $\mathbf{0 . 5 5}$ & $\mathbf{0 . 5 4}$ & -0.44 \\
$\gamma$-cadinene & $\mathbf{0 . 8 0}$ & -0.29 & 0.24 \\
$\delta$-cadinene & $\mathbf{0 . 7 2}$ & 0.49 & 0.31 \\
elemol & $\mathbf{- 0 . 5 8}$ & $\mathbf{0 . 6 2}$ & 0.41 \\
ledol & $\mathbf{0 . 9 8}$ & -0.07 & 0.05 \\
spathulenol & 0.40 & $\mathbf{- 0 . 6 5}$ & 0.31 \\
caryophyllene oxide & $\mathbf{0 . 9 2}$ & -0.20 & 0.08 \\
viridiflorol & $\mathbf{0 . 5 7}$ & $\mathbf{- 0 . 5 9}$ & 0.20 \\
$\mathrm{C}_{15} \mathrm{H}_{20} \mathrm{O} \mathrm{M}^{+}=218$ & $\mathbf{0 . 9 1}$ & -0.27 & 0.27 \\
eudesmol & -0.11 & $\mathbf{- 0 . 7 1}$ & 0.44 \\
\hline Eigenvalue & 10.85 & 4.18 & 2.33 \\
Cumulative explained variance & 51.68 & 71.58 & 82.67 \\
(\%) & & & \\
\hline
\end{tabular}

Note: Factor loadings higher than 0.50 are highlighted.

Indeed, cluster analysis is an exploratory data analysis tool which aims to sort different samples into groups in a way that the degree of association between two samples is maximal if they belong to the same group and minimal otherwise. Even though these multivariate methods were successfully applied in the current work, these results are only indications of grouping patterns due to the limited number of samples analyzed.

Thus, it is possible to assume that each group will have similar chemical compositions. All these data indicate there are no significant differences between the chemical compositions of samples coming from the states of Paraná and Santa Catarina and the strongest factor to discriminate the oils seems to be the plant organ.

The results presented here confirm a recent report that stated that significant differences between the chemical compositions of the volatile metabolites from male and female specimens of the Baccharis species can be minimized by collecting botanical materials in the same place and time. ${ }^{16}$

The observed variation in the chemical compositions of essential 


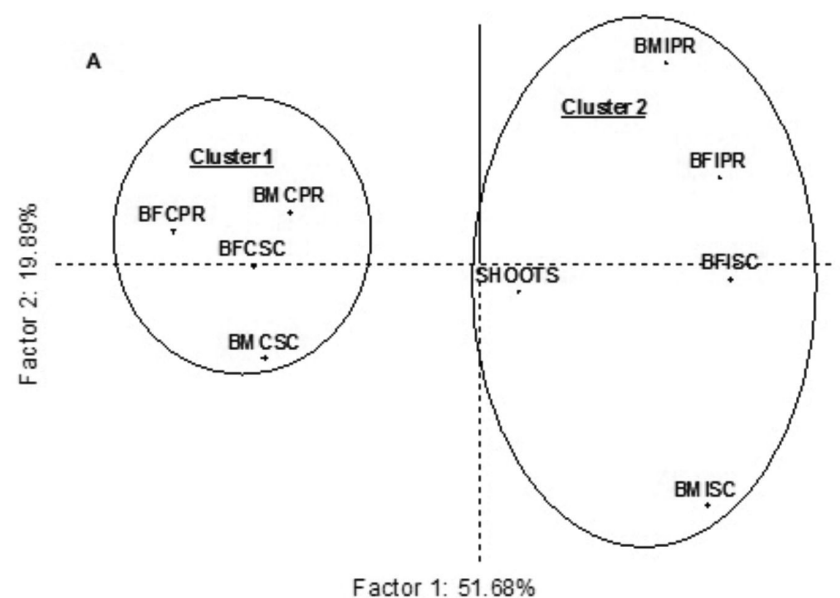

Factor 1: $51.68 \%$

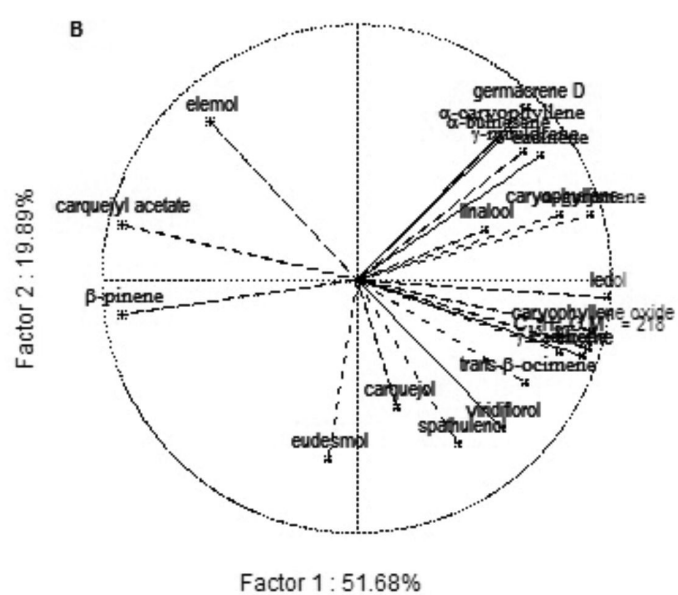

Figure 2. A) A scatter plot of PC 1 vs. PC 2 of the main sources of variability between the Baccharis trimera specimens; $\boldsymbol{B}$ ) Factor loading (variables) for PC 1 vs. PC 2. See Table 1 for the definition of sample abbreviations

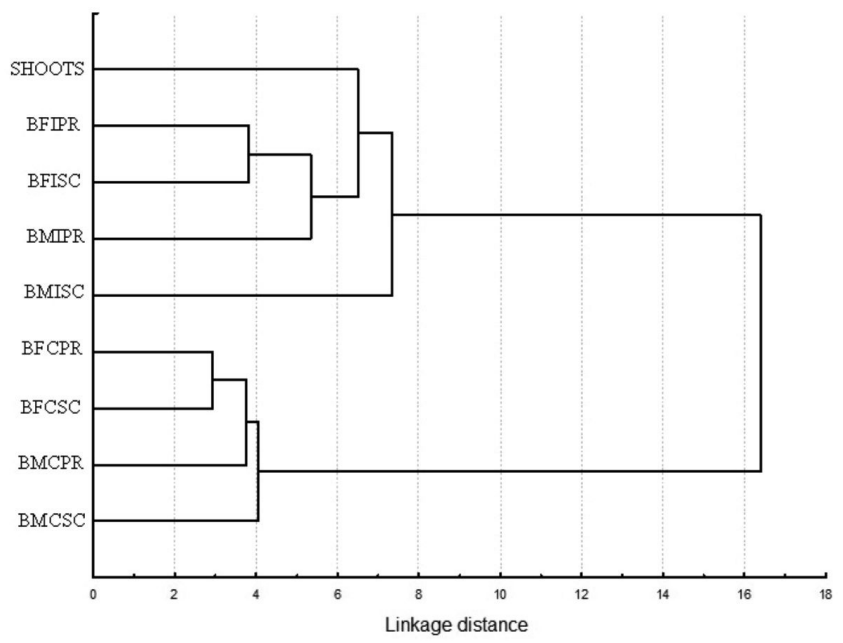

Figure 3. Hierarchical cluster analysis applied to the samples of Baccharis trimera (male and female specimens). See Table 1 for the definition of sample abbreviations

oils obtained from various samples of $B$. trimera, as published in the literature, can be used to organize the known samples into three groups. Firstly, carquejyl acetate is the main component in some cases with carquejol and ledol in minor proportions $;{ }^{11}$ this is in contrast to a second group of samples which have higher proportions of carquejol in comparison with carquejyl acetate and no ledol $;^{13}$ and in the third group there is a total absence of these componentes. ${ }^{5,14}$ This division suggests the existence of three chemotypes of the plant species $B$. trimera based on the proportions of carquejol, carquejyl acetate and ledol. This critical analysis points to the urgent need for a review of the botanical occurrences of this plant species in Southern and Southeast Brazil, since this species is widely commercialized and industrialized.

Once the groups were characterized using HCA, the averages of the chemical compounds were compared by the Student t-test for independent samples after checking for the homogeneity of variances by the F-test (Table 4); it was observed that the $\beta$-pinene, carquejyl acetate, elixene, $\alpha$-bulnesene, ledol, caryophyllene oxide and the unidentified $\mathrm{C}_{15} \mathrm{H}_{20} \mathrm{O} \mathrm{M}^{+}=\mathrm{m} / \mathrm{z} 218$ contents were statistically different ( $p<0.05$ ) between the 2 clusters. Thus, it can be inferred that the concentrations of these compounds were primarily responsible for the differentiation of samples included in the two groups. In the same sense, the contents of caryophyllene, germacene $\mathrm{D}, \delta$-cadinene and elemol seemed to be marginally different between the clusters, showing the usefulness of these compounds to serve as chemical markers for differentiating samples of volatile compounds in this study.

Table 4. Comparison between the two formed clusters

\begin{tabular}{lcccc}
\hline COMPONENT (\%) & Cluster 1 & Cluster 2 & PSD $^{1}$ & p-value $^{2}$ \\
\hline$\beta$-pinene & 2.22 & 0.48 & 1.06 & $<0.001$ \\
trans- $\beta$-ocimene & 0.27 & 0.35 & 0.09 & 0.35 \\
linalool & 0.48 & 0.52 & 0.14 & 0.84 \\
carquejol & 3.45 & 6.82 & 5.46 & 0.39 \\
carquejyl acetate & 69.69 & 43.66 & 14.42 & $<0.001$ \\
$\alpha$-gurjunene & 0.32 & 0.54 & 0.15 & 0.23 \\
caryophyllene & 0.36 & 1.90 & 1.11 & 0.09 \\
$\alpha$-caryophyllene & 0.38 & 0.70 & 0.35 & 0.35 \\
$\gamma$-muulorene & 0.29 & 0.48 & 0.23 & 0.56 \\
germacrene D & 3.77 & 6.29 & 2.14 & 0.07 \\
elixene & 1.75 & 4.27 & 1.65 & 0.01 \\
$\alpha$-bulnesene & 0.54 & 1.26 & 0.54 & 0.04 \\
$\gamma$-cadinene & 0.00 & 0.41 & 0.25 & na \\
$\delta$-cadinene & 0.75 & 1.34 & 0.46 & 0.05 \\
elemol & 0.56 & 0.27 & 0.25 & 0.08 \\
ledol & 7.10 & 15.43 & 4.62 & $<0.001$ \\
spathulenol & 0.14 & 0.26 & 0.20 & 0.45 \\
caryophyllene oxide & 0.00 & 0.47 & 0.27 & $<0.001$ \\
viridiflorol & 0.89 & 1.95 & 1.25 & 0.23 \\
$\mathrm{C}_{15} \mathrm{H}_{20} \mathrm{O} \mathrm{M}^{+.}=\mathrm{m} / \mathrm{z} 218$ & 1.92 & 3.38 & 0.95 & 0.01 \\
eudesmol & 4.26 & 3.73 & 1.34 & 0.59 \\
\hline
\end{tabular}

Note: ${ }^{1} \mathrm{PSD}=$ pooled standard deviation; ${ }^{2}$ Probability value obtained by the Student-t test for independent variables; ${ }^{3}$ na $=$ not applicable.

\section{CONCLUSIONS}

Differing from what was previously found, ${ }^{5}$ the results presented and discussed here suggested great similarity between the compositions of volatile compounds from male and female specimens of $B$. trimera, both from cladodes and inflorescences collected in distant regions of southern states of Brazil.

All samples analyzed in this study presented considerable concentrations of carquejol, carquejyl acetate and ledol in two different organs of male and female plants. This is an interesting result because the studied plant samples were collected in different regions, as well 
as far from each other. These data corroborate the occurrence of the same chemotype in the three southern states of Brazil, with carquejyl acetate acting as the principal chemical marker.

\section{ACKNOWLEDGEMENTS}

We thank Coordenação de Aperfeiçoamento de Pessoal de Nível Superior (CAPES) for a Master in Science scholarship (M. A. Besten), Conselho Nacional de Desenvolvimento Científico e Tecnológico (CNPq) (478229/2006-2) and Fundação Araucária (047/2007-1573) for financial support.

\section{SUPPLEMENTARY MATERIAL}

Photos of B. trimera and details of male and female inflorescences are available for free at http://quimicanova.sbq.org.br in a PDF file.

\section{REFERENCES}

1. Lonni, A. A. S. G.; Scarminio, I. S.; Silva, L. M. C.; Ferreira, D. T.; Anal. Sci. 2003, 19, 1013.

2. Barroso, G. M.; Rodriguésia 1976, $28,3$.

3. Heiden, G.; Iganci, J. R. V.; Macias, L.; Rodriguésia 2009, 60, 943.

4. Torres, L. M. B.; Gamberini, M. T.; Roque, N. F.; Lima-Landman, M. T.; Souccar, C.; Lapa, A. J.; Phytochemistry 2000, 55, 617; Nakasugi, T.; Komais, K.; J. Agric. Food Chem. 1998, 46, 2560; Januário, H.; Santos, S. L.; Marcussi, S.; Mazzi, M. V.; Pietro, R. C. L. R.; Sato, D. N.; Ellena, J.; Sampaio, S. V.; França, S. C.; Soares, M.; Chem. Biol. Interact. 2004, 150, 243; Dias, L. F. T.; Melo, E. S.; Hernandes, L. S.; Bacchi, E. M.; Rev. Bras. Farmacogn. 2009, 19, 309.

5. Lago, J. H. G.; Romoff, P.; Fávero, O. A.; Souza, F. O.; Soares, M. G.; Baraldi, P. T.; Corrêa, A. G.; Biochem. Syst. Ecol. 2008, 36, 737.
6. Cortadi, A.; Di Sapio, O.; McCargo, J.; Scandizzi, A.; Gattuso, S.; Gattuso, M.; Pharm. Biol. 1999, 35, 357; Gianello, J. C.; Ceñal, J. P.; Giordano, O. S.; Tonn, C. E.; Petenatti, M. E.; Petenatti, E. M.; Del Vitto, L. A.; Acta Farm. Bonaerense 2000, 19, 99.

7. Brandão, M. G. L.; Cosenza, G. P.; Moreira, R. A.; Monte-Mor, R. L. M.; Rev. Bras. Farmacogn. 2006, 16, 408.

8. Bona, C. M.; Biasi, L. A.; Zanette, F.; Nakashima, T.; Ciência Rural 2005, 35, 223.

9. Di Stasi, L. C.; Oliveira, G. P.; Carvalhaes, M. A.; Queiroz Jr, M.; Tien, O. S.; Kakinami, S. H.; Reis, M. S.; Fitoterapia 2002, 73, 69.

10. Matzenbacher, N. I.; Lima, L. F. P.; Dettke, G. A.; Durigon, J.; KielingRubio, M. A.; Trevisan, R.; Flórula da Fazenda São Maximiano, Guaíba, Rio Grande do Sul, Brasil. 1 1 ${ }^{\text {st }}$ ed., EDIURCAMP: Bagé, 2011.

11. Simões-Pires, C.; Debenedetti, S.; Spegazzini, E.; Mentz, L. A.; Matzenbacher, N. I.; Limberger, R. P.; Henriques, A. T.; Plant Syst. Evol. 2005, 253, 23.

12. Vargas, R. M. F.; Cassel, E.; Gomes, G. M. F.; Longhi, L. G. S.; AttiSerafini, L.; Atti-Santos, A. C.; Braz. J. Chem. Eng. 2006, 23, 375.

13. Carreira, R. C.; Doctoral Thesis, Instituto de Botânica Secretaria do Meio Ambiente, Brazil, 2007.

14. Silva, F. G.; Oliveira, C. B. A.; Pinto, J. E. B. P.; Nascimento, V. E.; Santos, S. C.; Seraphin, J. C.; Ferri, P. H.; J. Braz. Chem. Soc. 2007, 18, 990; Lago, J. H. G.; Romoff, P.; Fávero, O.; Soares, M. G.; Baraldi, P. T.; Corrêa, A. G.; Souza, F. O.; Quim. Nova 2008, 31, 727.

15. Stahl, E.; Schild, W.; Pharmazeutische Biologie, 4: Drogenanalyse IIInhaltsstoffe und Isolierungen. $1^{\text {st }}$ ed., Gustav Fischer Verlag: Stuttgart, 1981.

16. Besten, M. A.; Jasinski, V. C. G.; Costa, A. G. L. C.; Nunes, D. S.; Sens, S. L.; Simionatto, E. L.; Wisniewski Jr, A.; Riva, D.; Dalmarco, J. B.; Granato, D.; J. Braz. Chem. Soc. 2012, 23, 1041.

17. Kaiser, H. F.; Psychometrika 1958, 23, 141.

18. Granato, D.; Katayama, F. C. U.; Castro, I. A.; J. Sci. Food Agric. 2012, 92, 526. 


\section{CHEMICAL COMPOSITION OF VOLATILES FROM MALE AND FEMALE SPECIMENS OF Baccharis trimera COLLECTED IN TWO DISTANT REGIONS OF SOUTHERN BRAZIL: A COMPARATIVE STUDY USING CHEMOMETRICS}

Michele Aparecida Besten and Domingos Sávio Nunes*

Departamento de Química, Universidade Estadual de Ponta Grossa, Av. Carlos Cavalcanti 4748, 84030-900 Ponta Grossa - PR, Brasil Alberto Wisniewski Jr.

Departamento de Química, Universidade Federal de Sergipe, Rod. Mal. Rondon S/N, 49100-000 São Cristóvão - SE, Brasil Sávio Luis Sens

Centro de Educação Tecnológica Irmão Mário Cristóvão (TECPUC), Rua Imaculada Conceição 1155, 80215-901 Curitiba - PR, Brasil

\section{Daniel Granato}

Núcleo de Análise e Tratamento de Dados, Instituto Adolfo Lutz, Av. Dr. Arnaldo 355, 01246-902 São Paulo - SP, Brasil Edésio Luis Simionatto, Dilamara Riva Scharf and Juliana Bastos Dalmarco

Laboratório de Cromatografia, Fundação Universidade Regional de Blumenau, Rua São Paulo 3250, 89030-000 Blumenau - SC, Brasil

Nelson Ivo Matzenbacher

Departamento de Botânica, Universidade Federal do Rio Grande do Sul, Av. Bento Gonçalves 9500, B1. 4, Prédio 43433, 91540-000 Porto Alegre - RS, Brasil

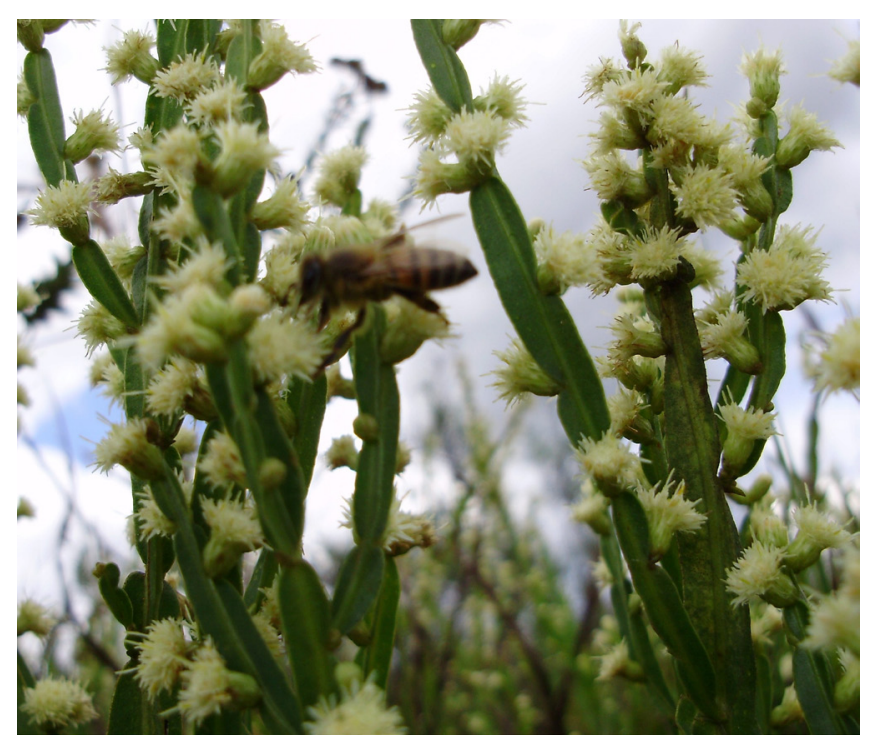

Figure 1S. Male specimens of Baccharis trimera are visited by bees and other insects looking for food

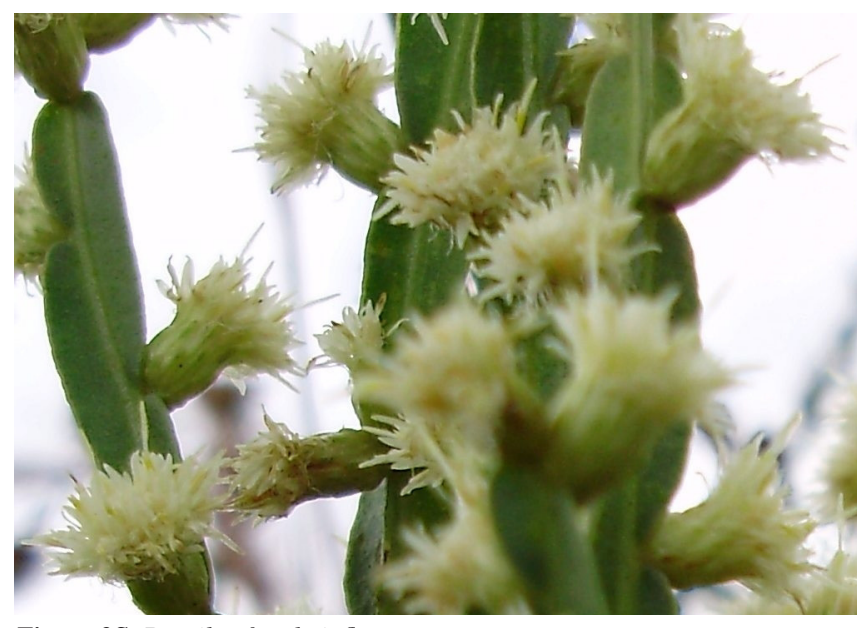

Figure 2S. Details of male inflorescences 


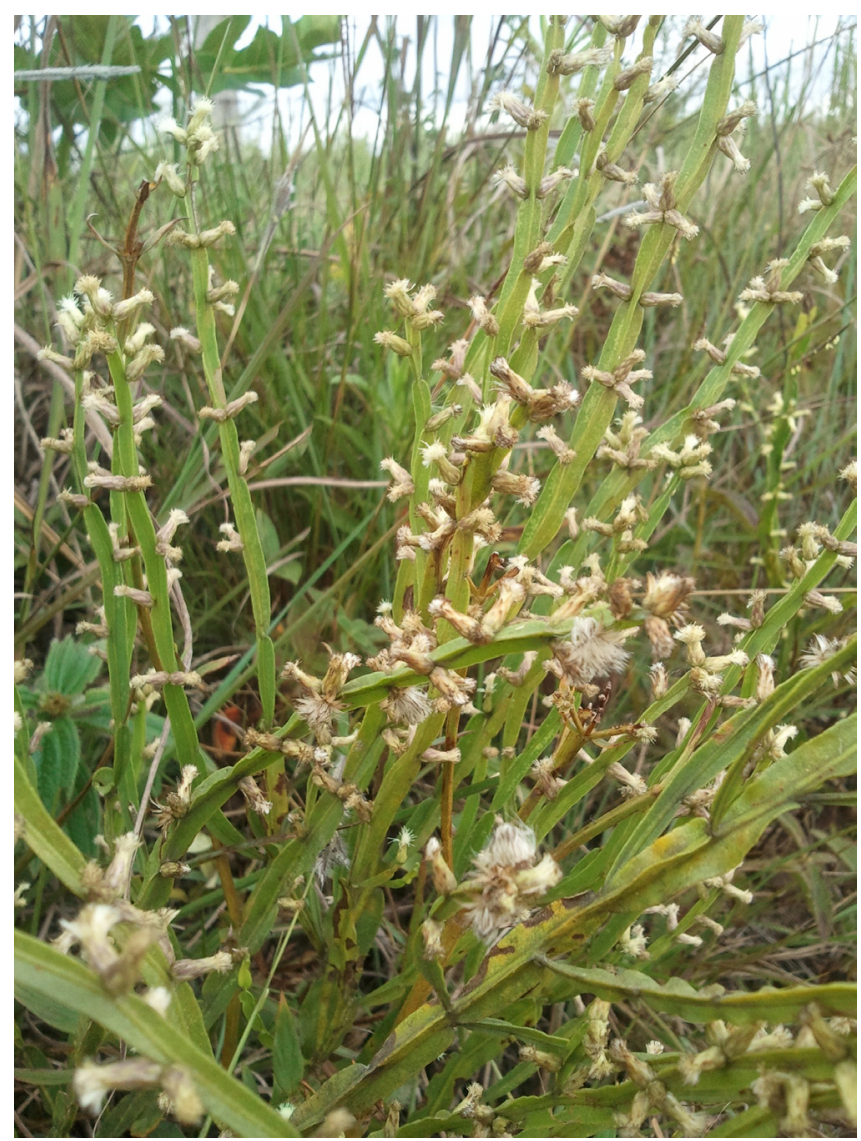

Figure 3S. Female specimen of B. trimera at the end of the flowering season

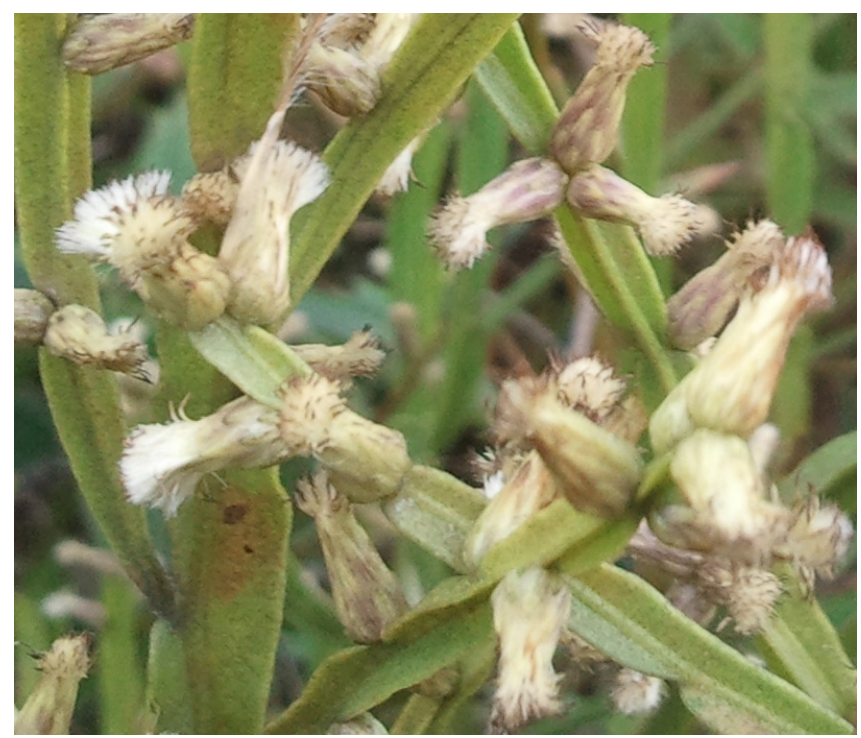

Figure 4S. Details of female inflorescences 